\title{
Perbandingan Sistem Perhitungan Suara Tepuk Tangan dengan Metode Berbasis Frekuensi dan Metode Berbasis Amplitudo
}

\section{Comparison of Applause Calculation Systems using Frequency- Based Method and Amplitude-Based Method}

\author{
PUSPITA KARTIKA SARI*, KARLISA PRIANDANA, AGUS BUONO
}

\begin{abstract}
Abstrak
Sistem penilaian berdasarkan suara tepuk tangan sering digunakan dalam acara perlombaan di Indonesia. Namun, penentuan pemenang dengan cara konvensional cenderung subjektif. Penelitian ini mengembangkan sistem penilaian otomatis berbasis komputer untuk menghitung jumlah orang bertepuk tangan dan menentukan pemenang dari perlombaan berdasarkan tepuk tangan. Penelitian ini membandingkan dua metode yang dapat diterapkan yaitu metode berbasis frekuensi dan metode berbasis amplitudo. Metode yang berbasis frekuensi mengimplementasikan Mel Frequency Cepstral Coefficient (MFCC) sebagai pengekstraksi ciri dan codebook sebagai pengenal pola. Hasil yang diperoleh merupakan suatu model berupa kelas-kelas yang diklasterkan oleh K-Means clustering. Parameter penting dalam metode ini adalah jumlah koefisien cepstral, overlap, time frame, dan jumlah klaster. Beberapa pengujian dilakukan untuk menemukan parameter optimum dengan nilai akurasi tertinggi. Metode kedua merupakan metode berbasis amplitudo yang dilakukan dengan menghitung jumlah sampel sinyal yang memiliki nilai amplitudo di atas nilai-nilai ambang (thresholds) tertentu yang menghasilkan akurasi maksimum. Hasil penelitian menunjukkan bahwa akurasi sistem berbasis frekuensi untuk tepuk tangan periodik adalah $83.3 \%$ dan untuk tepuk tangan acak ialah 50\% sehingga akurasi sistem untuk tepuk tangan acak berbasis threshold yang lebih sederhana ialah $66.7 \%$. Dengan demikian, metode berbasis amplitudo baik digunakan.
\end{abstract}

Kata kunci: Codebook, K-means, Mel Frequency Cepstral Coefficients (MFCC), Pengenalan Suara, Threshold

\begin{abstract}
Scoring system based on sound of applause is often used in many contests in Indonesia. However, determining the winner in a conventional way tend to be subjective. This research develops automated computer-based scoring system to count the number of people who applauded and determine the winner of a competition based on applause. This research compares two methods that can be adopted: frequency-based method and amplitude-based method. Frequency-based method utilizes Mel Frequency Cepstral Coefficient (MFCC) for feature extraction and Codebook for pattern recognition. They produce a model in the form of classes that are clustered by K-Means clustering. The important parameters in this method are the number of cepstral coefficients, overlap, the time frame, and the number of clusters. Several tests are conducted to find the optimum parameters with maximum accuracy. The second method is amplitude-based method by counting the number of signal samples with amplitude above a certain threshold value that can produce the maximum accuracy. It is found that the accuracy of frequency-based system for periodic applause is $83.3 \%$, whereas that for real applause is 50\%. Meanwhile, the accuracy of a simpler threshold-based system for real applause is $66.7 \%$. Thus, this study recommends the usage of amplitude-based method for this application.
\end{abstract}

Keywords: Codebook, K-means, Mel Frequency Cepstral Coefficients (MFCC), Speaker Recognition, Threshold

\section{PENDAHULUAN}

Sistem penilaian berdasarkan suara tepuk tangan sering digunakan dalam acara perlombaan di Indonesia. Pemenang ditentukan berdasarkan suara tepuk tangan terbanyak dari para penontonnya, namun pembawa acara, juri, atau siapapun yang menentukan pemenang berdasarkan tepuk tangan cenderung subjektif. Penggunaan komputer sebagai 
sistem penilaian merupakan salah satu solusi yang dapat dilakukan, karena sifat komputer yang tidak subjektif dan konsisten terhadap tugas yang diperintahkan.

Pada proses pengenalan jumlah orang yang bertepuk tangan, salah satu fitur yang penting untuk dianalisis adalah frekuensi. Metode Mel Frequency Cepstral Coefficients (MFCC), Linear Predictive Cepstral Coefficients (LPCC), dan Wavelet sering digunakan untuk mengekstraksi fitur dalam domain frekuensi pada suara. Metode LPCC memiliki keunggulan dalam hal komputasi yang lebih sederhana, namun tingkat akurasinya tidak sebaik MFCC (Li dan Chang 2003). Pernyataan ini diperkuat bahwa, dalam pengenalan suara, MFCC dapat merepresentasikan sinyal lebih baik dibandingkan dengan LPCC dan teknik lainnya (Ganchev 2005). Penelitian lain menyimpulkan bahwa penggunaan metode Wavelet sebagai ekstraksi ciri pada pengenalan pola tidak memberikan hasil yang lebih baik daripada penggunaan metode MFCC (Taufani 2011). Oleh karena itu, metode MFCC digunakan pada penelitian ini sebagai metode berbasis frekuensi untuk mengekstraksi ciri. Kelebihan utama dari MFCC ialah dapat meniru perilaku dari telinga manusia. Setelah ekstraksi ciri, langkah lain yang diperlukan ialah pengenalan pola. Pada penelitian ini, metode codebook akan digunakan untuk melakukan pengenalan pola.

Selain frekuensi, fitur lain yang penting untuk diamati pada pengenalan jumlah orang yang bertepuk tangan ialah amplitudo. Dalam penelitian ini metode berbasis amplitudo adalah metode threshold, dengan cara menghitung jumlah sampel sinyal suara yang memiliki amplitudo di atas nilai tertentu.

Sistem yang dikembangkan dalam penelitian ini ialah prototype dengan fokus utama pada tahapan pemodelan dan pengujian identifikasi suara tepuk tangan. Prototype yang dikembangkan hanya dapat melakukan identifikasi suara tepuk tangan maksimal untuk 10 orang. Prototype ini diharapkan dapat menjadi dasar pengembangan sistem identifikasi suara tepuk tangan.

\section{METODE}

Pada penelitian ini, terdapat dua metode utama yang diimplementasikan yaitu metode berbasis frekuensi dan metode berbasis amplitudo. Alur penelitian secara umum ditunjukkan pada Gambar 1.

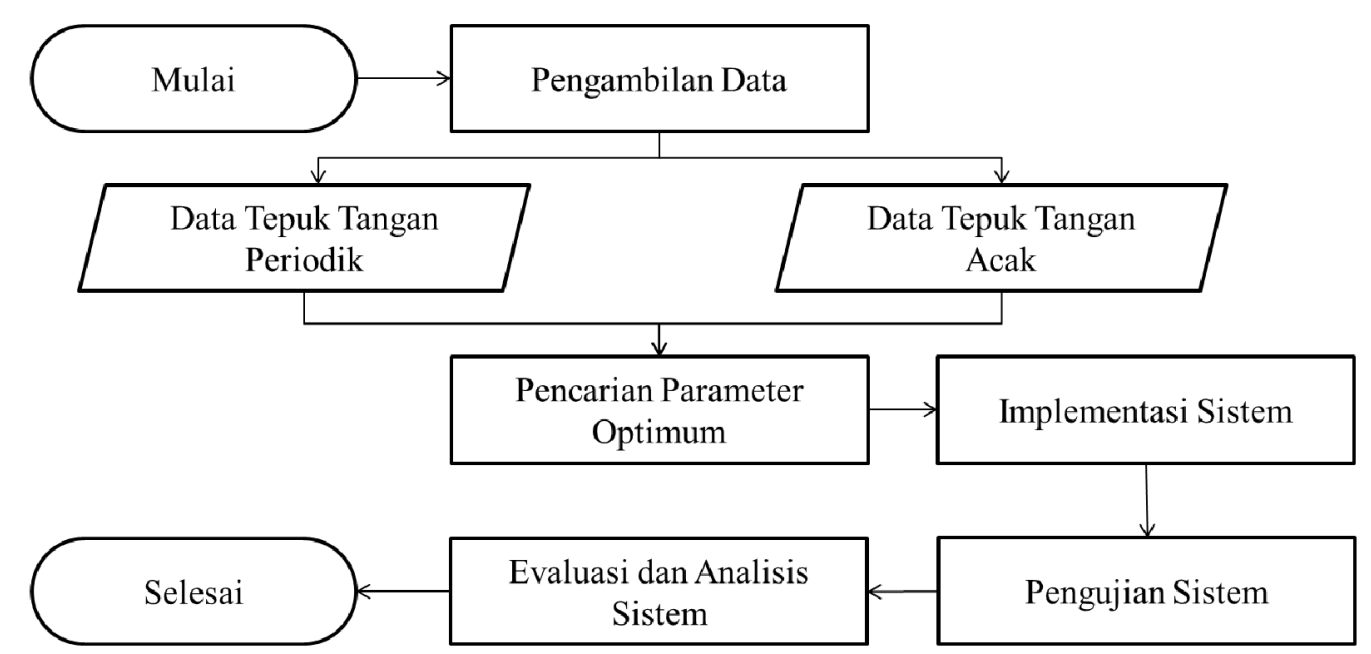

Gambar 1 Alur penelitian 
Untuk sistem berbasis frekuensi yang lebih kompleks, terdapat dua subalur yang terdiri atas pemrosesan data tepuk tangan periodik (Gambar 2) dan pemrosesan data tepuk tangan acak (Gambar 3). Data tepuk tangan acak diperlukan agar sistem dapat diimplementasikan untuk mengenali tepuk tangan secara real time.

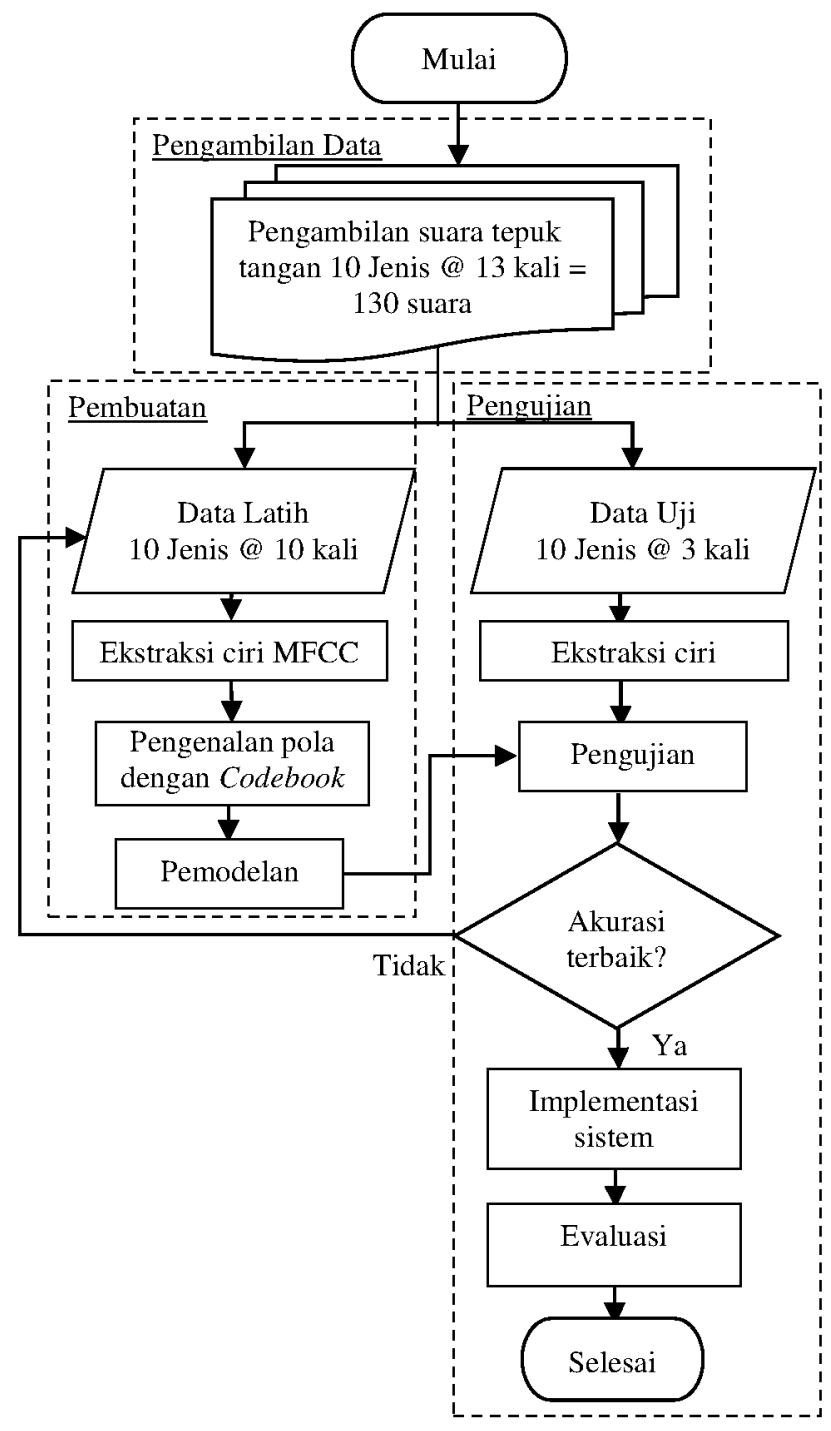

Gambar 2 Proses sistem penilaian otomatis dengan data tepuk tangan periodik untuk mencari parameter optimum

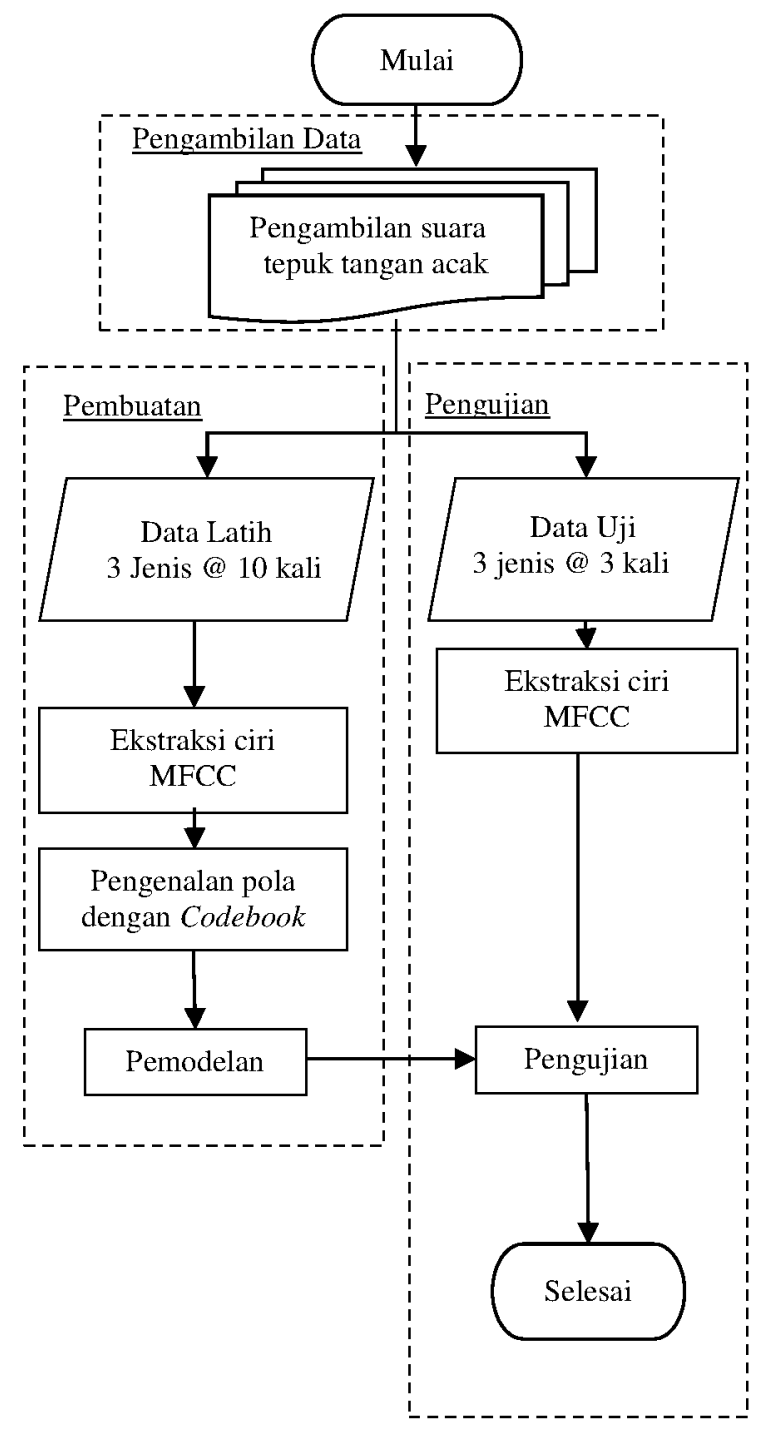

Gambar 3 Proses pembuatan sistem penilaian otomatis dengan data tepuk tangan acak

\section{Data Tepuk Tangan Periodik}

Data suara yang digunakan pada penelitian ini berasal dari 10 orang. Terdapat 10 jenis kelas tepuk tangan yang diambil, yaitu kelas tepuk tangan 1 dengan hanya satu orang yang bertepuk tangan, kelas tepuk tangan 2 dengan dua orang bertepuk tangan, dan seterusnya hingga kelas tepuk tangan 10 dengan semua (10) orang bertepuk tangan. Tiap kelas tepuk tangan direkam sebanyak 13 kali, masing-masing dalam waktu yang berbeda. File data suara disimpan dalam bentuk fail WAV dan setiap perekaman suara menggunakan sampling rate $11000 \mathrm{~Hz}$. Dari 13 data suara dari masing-masing kelas, sebanyak 10 data dijadikan data latih dan 3 data suara lainnya dijadikan data uji.

Data latih diproses dengan ekstraksi ciri MFCC, pengenalan pola codebook, dan pemodelan $K$-means clustering untuk menghasilkan suatu model sebagai alat penentu keputusan dari hasil pengujian. Setelah itu, data uji akan diproses dengan ekstraksi ciri MFCC kemudian dicocokkan dengan model sehingga didapatkan hasil klasifikasi tepuk tangan. 


\section{Data Tepuk Tangan Acak}

Kelas yang dibuat berupa rentang, yaitu kelas 1 dengan 0-2 orang bertepuk tangan, kelas 2 dengan 3-7 orang bertepuk tangan, dan kelas 3 dengan lebih dari 7 orang bertepuk tangan. Masing-masing kelas memiliki 13 data yang dibagi menjadi 10 data latih dan 3 data uji.

\section{Ekstraksi Ciri dengan MFCC}

Gambar 4 menjelaskan mengenai tahapan ekstraksi ciri dengan teknik MFCC (Buono 2009).

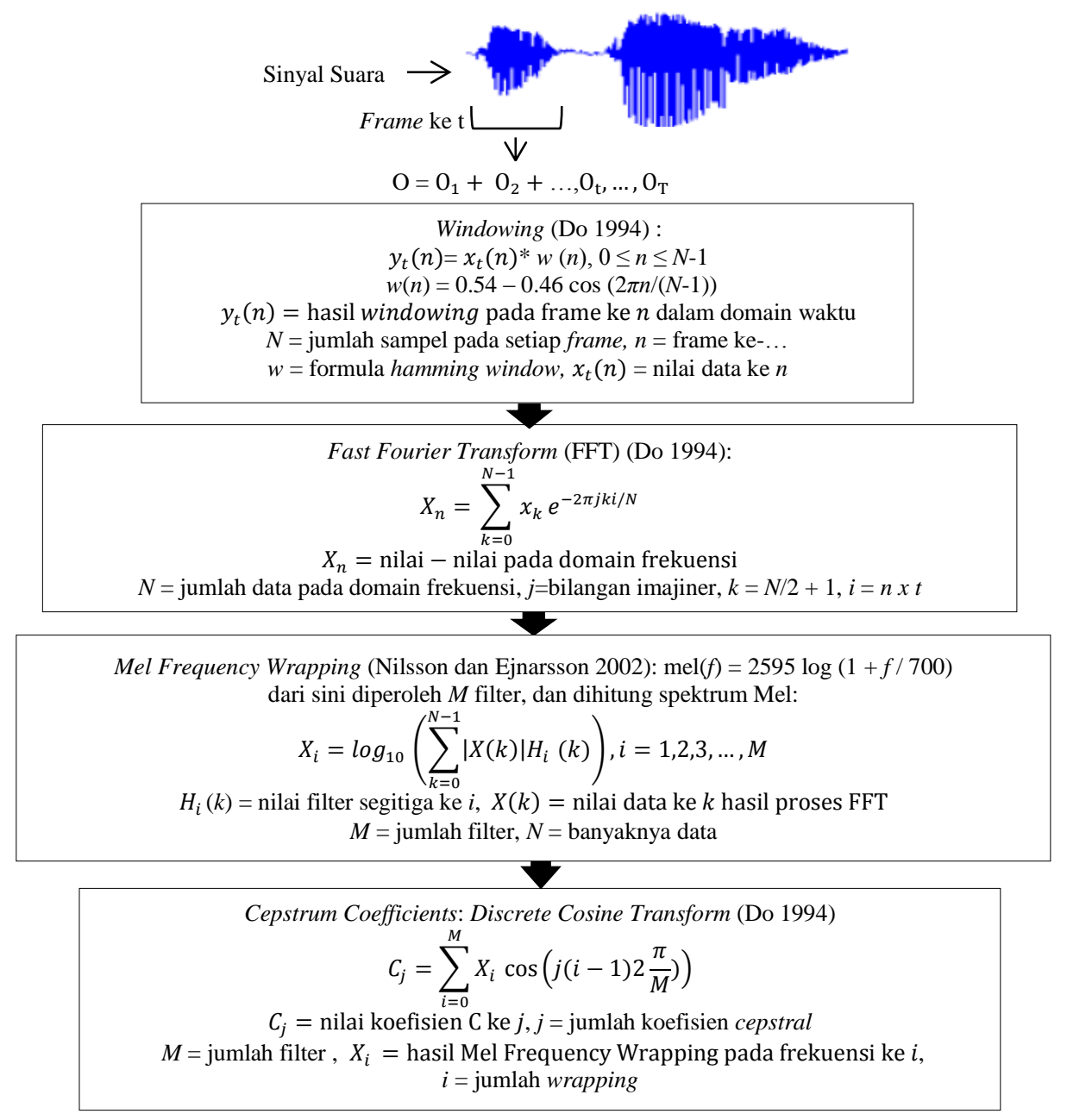

Gambar 4 Diagram alur mel frequency cepstral coefficients

Pada proses frame blocking, sinyal suara disegmentasi menjadi beberapa frame yang saling tumpang tindih (overlap) (Gambar 4) agar tidak ada sedikitpun sinyal yang hilang (deletion). Sinyal dibaca dari frame ke frame dengan nilai overlap tertentu lalu dilakukan windowing untuk setiap frame. Selanjutnya, transformasi Fourier dilakukan untuk mengubah dimensi suara dari domain waktu ke domain frekuensi. Dari hasil transformasi Fourier, spectrum mel dihitung menggunakan sejumlah filter yang dibentuk untuk mengikuti persepsi sistem pendengaran manusia. Proses ini dikenal dengan Mel Frequency Wrapping. Koefisien MFCC atau koefisien cepstrum merupakan hasil transformasi Cosinus dari spectrum mel yang diperoleh.

\section{Pengenalan Pola dengan Codebook}

Pengenalan pola dengan codebook dilakukan untuk data latih, setelah vektor ciri diperoleh dari proses MFCC. Codebook dibuat untuk setiap data yang telah direkam dan terdiri atas beberapa codeword untuk merepresentasikan ciri suara. Codebook dibentuk 
dengan cara membentuk klaster atau kelompok dari semua vektor ciri data latih dengan menggunakan suatu clustering algorithm. Algoritma clustering yang digunakan adalah $K$ means.

\section{Pengujian}

Pengujian dilakukan pada ciri data uji yang dihasilkan dari proses ekstraksi ciri MFCC dengan menggunakan model codebook dari data latih. Output yang dihasilkan berupa jumlah orang yang bertepuk tangan. Tingkat akurasi sistem dihitung untuk mengevaluasi hasil penelitian. Persentase tingkat akurasi dihitung dengan rumus sebagai berikut:

$$
\text { hasil akurasi }=\frac{\text { jumlah suara yang benar }}{\text { jumlah suara yang diuji }} \times 100 \%
$$

Pengujian dilakukan berulang-ulang dengan mengubah nilai-nilai parameter (jumlah koefisien cepstral, overlap, time frame, dan jumlah klaster) untuk mendapatkan hasil akurasi maksimum.

\section{HASIL DAN PEMBAHASAN}

\section{Pengembangan Sistem Berbasis Frekuensi}

Terdapat lima parameter yang harus dimasukkan pada fungsi MFCC yang dibuat, yaitu vektor suara, sampling rate, time frame, overlap, dan jumlah cepstral coefficient. Vektor suara diperoleh dari data suara yang diubah menjadi vektor. Dalam hal ini, sampling rate yang digunakan adalah $11000 \mathrm{~Hz}$. Nilai parameter lainnya (time frame, overlap, dan jumlah cepstral coefficient) diubah-ubah hingga diperoleh nilai parameter-parameter yang optimum.

Pada proses pembuatan model codebook, data yang digunakan adalah data latih yang sudah berupa vektor ciri, hasil dari tahap MFCC. Data latih tersebut kemudian dikelompokkan dengan menggunakan $K$-means clustering. Jumlah klaster yang diujicobakan pada proses $K$-means ialah 2, 3, 4, dan 5 .

Pada penelitian ini, parameter-parameter yang diujicobakan ialah:

1 time frame sebesar $\{10,20,30,40,50,60,70,80,90,100\} \mathrm{ms}$, 2 jumlah klaster pada $K$-means sebanyak 2, 3, 4, 5, 3 jumlah koefisien cepstral sebanyak 13 dan 26, dan 4 overlap sebesar $0.25,0.3,0.35,0.4,0.45,0.5,0.6,0.75$.

Pengaruh time frame terhadap tingkat akurasi (Gambar 5) tidak terlihat jelas. Sementara itu, semakin banyak jumlah klaster, maka semakin baik akurasi yang dihasilkan. Akurasi pada saat klaster sebanyak 5 dan time frame sebesar $10 \mathrm{~ms}$ menghasilkan nilai akurasi terbaik $(83.3 \%)$.

Jumlah koefisien cepstral dan frame menampung vektor ciri suara. Ketika koefisien sebesar 13, akurasi maksimum yang dihasilkan yaitu $80 \%$ sedangkan jumlah koefisien cepstral sebesar 26 menghasilkan akurasi maksimum sebesar 83.3\% (Gambar 6). Jadi, nilai koefisien tidak terlalu berpengaruh.

Tingkat akurasi maksimum berada pada saat overlap sebanyak 0.4, sedangkan, akurasi minimum yaitu $63.3 \%$ ketika overlap sebesar 0.25 dan 0.6 (Gambar 7). Nilai overlap 0.25 dianggap terlalu sedikit menangkap informasi yang hilang ketika proses frame blocking, sebaliknya dengan overlap 0.6 akan terlalu banyak mengambil informasi suara yang justru tidak diperlukan. 


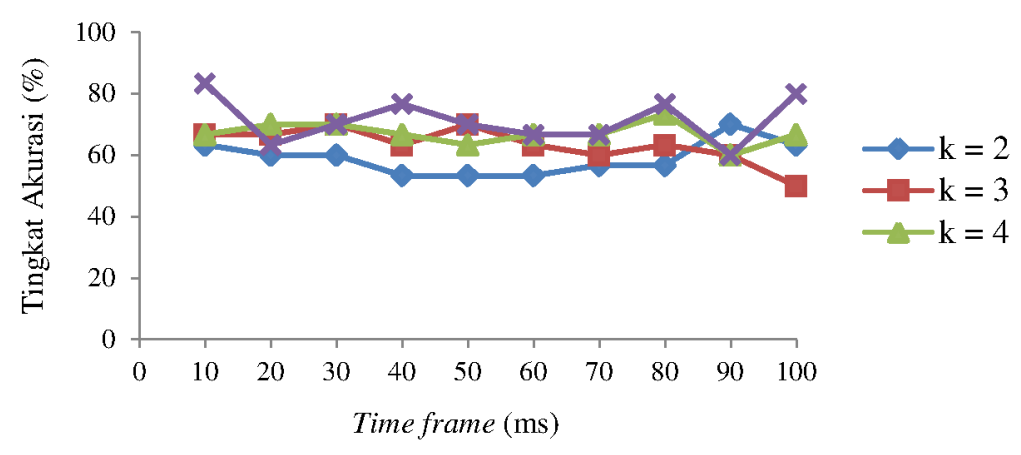

Gambar 5 Pengaruh nilai time frame dan jumlah klaster pada tingkat akurasi dengan jumlah koefisien cepstral $10 \mathrm{~ms}$ dan overlap 0.4

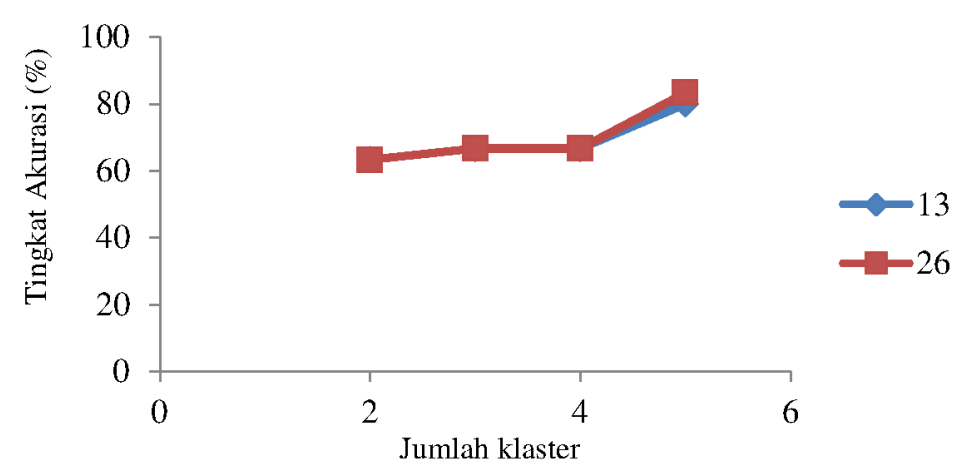

Gambar 6 Pengaruh nilai koefisien cepstral terhadap tingkat akurasi dengan overlap 0.4

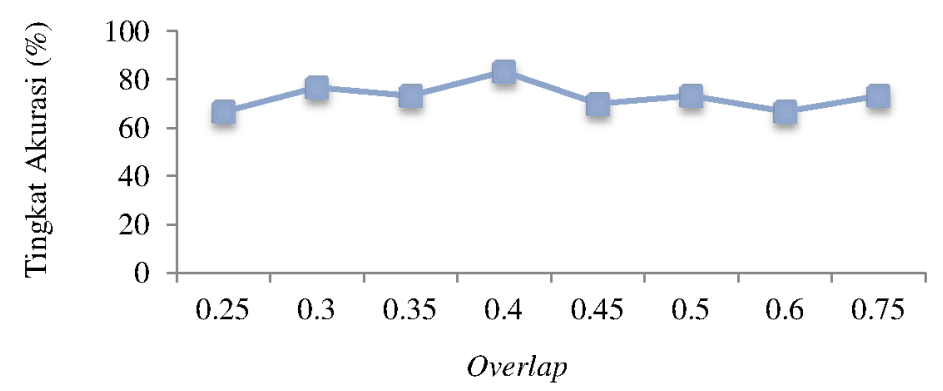

Gambar 7 Pengaruh overlap pada tingkat akurasi dengan jumlah koefisien cepstral 26, jumlah klaster5, dan time frame $10 \mathrm{~ms}$

Sistem dibuat untuk tepuk tangan acak dengan menggunakan parameter optimum. Gambar 8 merupakan antarmuka sistem yang memiliki 3 fungsi utama, yaitu record, recognize, dan reset. Fungsi record dibuat untuk merekam suara tepuk tangan, fungsi recognize dibuat untuk mengidentifikasi suara tepuk tangan, dan reset untuk mengembalikan antarmuka seperti awal. Tiga data uji dibandingkan untuk menentukan pemenang. Identifikasi ditampilkan dalam rentang nilai 0-2 orang, 3-7 orang, dan lebih dari 7 orang.

Walaupun pencarian parameter optimum (dengan data tepuk tangan periodik) menghasilkan akurasi $83.3 \%$, hasil pengujian sistem dengan tepuk tangan secara langsung (real time) hanya 50\% (Tabel 1). Pengujian langsung ini dilakukan sebanyak 10 kali untuk setiap kelas. 


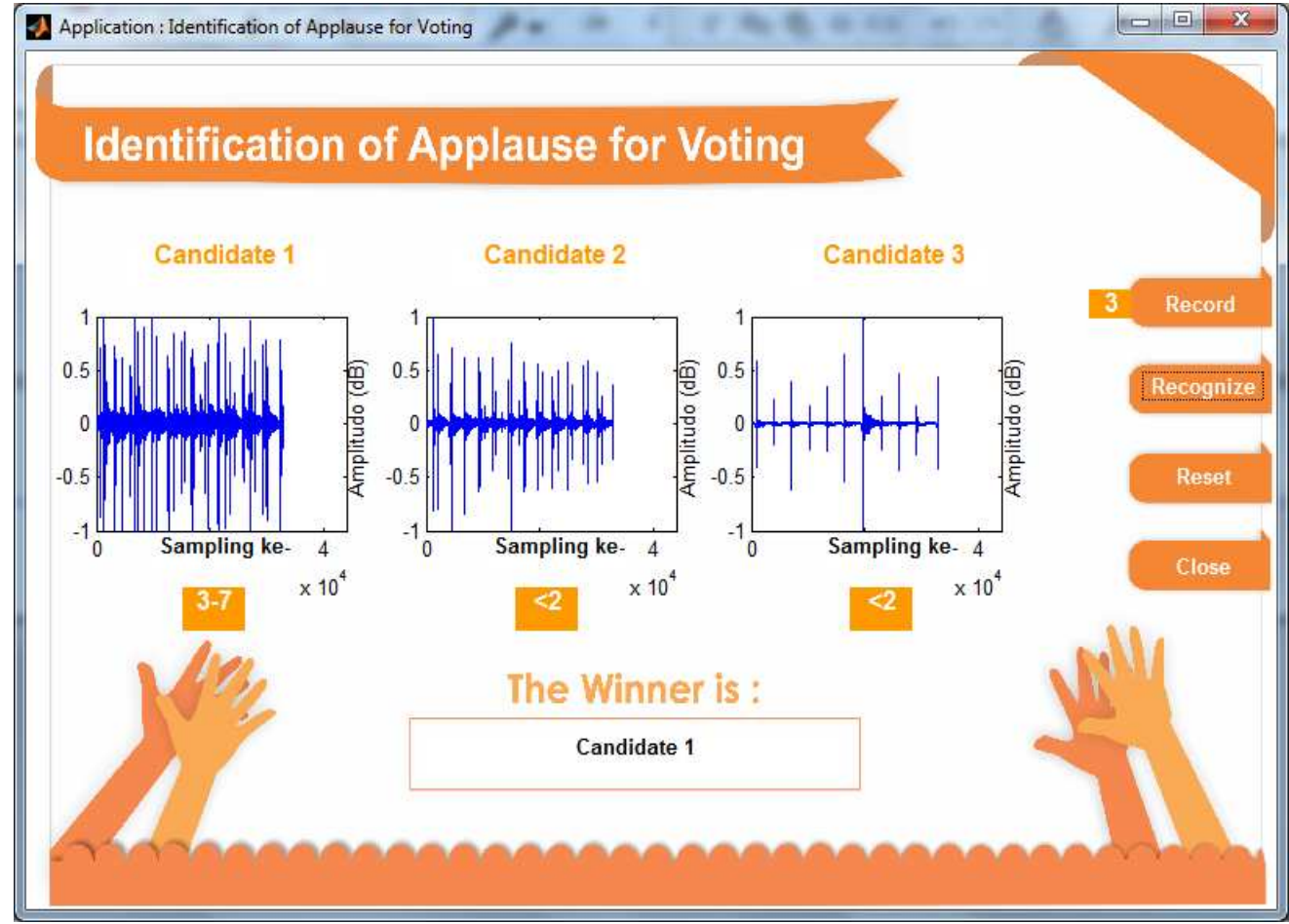

Gambar 8 Tampilan antarmuka Sistem Identifikasi Tepuk Tangan

Tabel 1 Matriks konfusi hasil pengujian langsung data tepuk tangan acak dengan MFCC

\begin{tabular}{cccc}
\hline Pktual & Kelas 1 & Kelas 2 & Kelas 3 \\
\hline Kelas 1 & 4 & 6 & 0 \\
Kelas 2 & 2 & 6 & 2 \\
Kelas 3 & 0 & 5 & 5 \\
\hline
\end{tabular}

Keterangan: Akurasi $=\frac{15}{30} \times 100 \%=50 \%$

Beberapa faktor yang menyebabkan penurunan hasil akurasi pada pengujian langsung ialah adanya noise yang disebabkan oleh lingkungan, variasi setiap suara tepuk tangan, distorsi alat/hardware, dan terbatasnya jumlah data latih. Faktor lain yang menyebabkan turunnya hasil akurasi ialah pemilihan metode pengenalan suara. Metode MFCC menggunakan power spectrum sebagai penentu ciri. Power spectrum bersifat sensitif terhadap gangguan noise. Dari fakta ini dapat disimpulkan bahwa rendahnya akurasi disebabkan oleh kelemahan dari metode yang digunakan untuk menangkap ciri sinyal. Oleh karena itu, percobaan menggunakan metode sederhana berbasis amplitudo dengan menentukan suatu nilai threshold dilakukan.

\section{Pengembangan Sistem Berbasis Threshold}

Metode ini diimplementasikan dengan cara menghitung jumlah sampel sinyal yang memiliki nilai amplitudo lebih dari suatu threshold tertentu. Dalam hal ini, beberapa nilai threshold diujicobakan hingga diperoleh nilai threshold optimum yang mengasilkan akurasi maksimum. Sama seperti pada metode berbasis frekuensi dengan tepuk tangan acak, percobaan yang dilakukan mencakup 3 kelas yaitu kelas 1 (0-2 orang bertepuk tangan), kelas 2 (3-7 orang bertepuk tangan), dan kelas 3 (lebih dari 7 orang bertepuk tangan). Tabel 2 menunjukkan rata-rata jumlah sampel yang memiliki nilai amplitudo di atas threshold tertentu, yaitu $0.1,0.2,0.3,0.4$, dan $0.5 \mathrm{~dB}$ untuk masing-masing kelas.

Pengujian langsung dilakukan sebanyak 10 kali untuk masing-masing kelas. Untuk setiap data uji, dilakukan perhitungan jumlah sampel yang memiliki nilai amplitudo di atas niilai-nilai threshold yang telah ditentukan. Selanjutnya, jumlah sampel tersebut dibandingkan 
dengan model kelas seperti yang ditunjukkan pada Tabel 2. Data uji diklasifikasikan berdasarkan selisih minimum antara jumlah sampel data uji dengan jumlah sampel pada model masing-masing kelas.

Gambar 9 menunjukkan perbandingan hasil akurasi berdasarkan nilai threshold yang dipilih. Nilai threshold $0.4 \mathrm{~dB}$ menghasilkan akurasi maksimum, sedangkan nilai threshold $0.1 \mathrm{~dB}$ menghasilkan akurasi minimum yaitu 50\%. Hal ini menunjukkan bahwa nilai threshold 0.1 tidak dapat mewakili suara tepuk tangan secara jelas. Nilai threshold $0.5 \mathrm{~dB}$ juga tidak menunjukkan akurasi sebaik nilai threshold 0.4 . Hal ini bisa terjadi disebabkan, nilai 0.5 terlalu tinggi untuk dijadikan batas sehingga ciri suara tidak dapat dikenal dengan baik. Tabel 3 menunjukkan bahwa akurasi sistem berbasis amplitudo dengan nilai threshold $0.4 \mathrm{~dB}$ adalah $66.7 \%$.

Tabel 2 Pemodelan jumlah sampel tiap kelas berdasarkan nilai threshold amplitudo

\begin{tabular}{lccccc}
\hline \multirow{2}{*}{ Jumlah Sampel } & \multicolumn{5}{c}{ Amplitudo (dB) } \\
\cline { 2 - 6 } & $\geq 0.1$ & $\geq 0.2$ & $\geq 0.3$ & $\geq 0.4$ & $\geq 0.5$ \\
\hline Kelas 1 & 1338 & 473 & 202 & 77 & 36 \\
Kelas 2 & 2176 & 887 & 471 & 312 & 246 \\
Kelas 3 & 3440 & 1334 & 786 & 492 & 321 \\
\hline
\end{tabular}

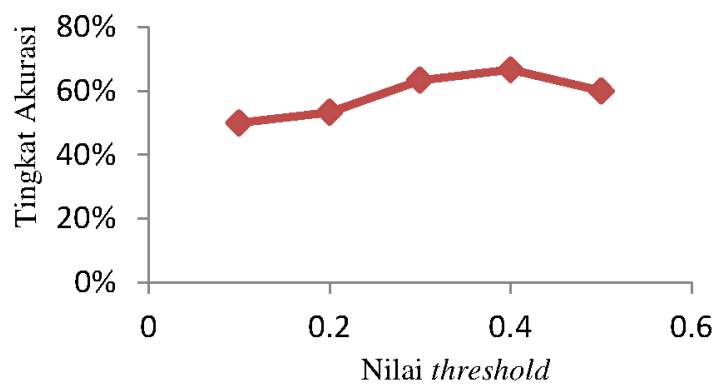

Gambar 9 Perbandingan hasil akurasi berdasarkan nilai threshold

Tabel 3 Matriks konfusi hasil pengujian langsung data tepuk tangan acak dengan threshold 0.4

\begin{tabular}{|c|c|c|c|}
\hline Aktual & Kelas 1 & Kelas 2 & Kelas 3 \\
\hline Kelas 1 & 7 & 3 & $\overline{0}$ \\
\hline Kelas 2 & 3 & 6 & 1 \\
\hline Kelas 3 & 0 & 3 & 7 \\
\hline
\end{tabular}

\section{SIMPULAN DAN SARAN}

Implementasi metode berbasis frekuensi dengan MFCC dan Codebook menunjukkan bahwa nilai-nilai parameter yang dipilih sangat mempengaruhi akurasi sistem. Semakin besar jumlah klaster pada tahap pemodelan kelas, maka nilai akurasi sistem akan semakin baik.

Hasil evaluasi sistem menunjukkan bahwa metode threshold yang berbasis amplitudo menghasilkan akurasi $66.7 \%$. Hasil ini lebih baik dibandingkan dengan metode MFCC berbasis frekuensi yang hanya menghasilkan akurasi $50 \%$. Hal ini menunjukkan bahwa metode berbasis frekuensi tidak cocok diterapkan untuk aplikasi perhitungan banyaknya orang yang bertepuk tangan, namun lebih cocok untuk mengidentifikasi suatu jenis suara tertentu, misalnya untuk membedakan suara manusia. Untuk aplikasi perhitungan suara tepuk tangan, metode yang lebih cocok diterapkan ialah metode berbasis amplitudo. 


\section{DAFTAR PUSTAKA}

Buono A. 2009. Representasi nilai HOS dan model MFCC sebagai ekstraksi ciri pada sistem identifikasi pembicara di lingkungan ber-noise menggunakan HMM. [Disertasi]. Depok (ID): Universitas Indonesia.

Buono A, Kusumoputro B. 2007. Pengembangan model HMM berbasis maksimum lokal menggunakan jarak Euclid untuk sistem identifikasi pembicara. Di dalam: Prosiding pada workshop NACSIIT; 2007 Jan 29-30; Depok, Indonesia. hlm 49-54.

Do MN. 1994. Digital Signal Processing Mini-Project: An Automatic recognition System. Audio Visual Communication Laboratory, Swiss Federal Institute of Technology, Switzerland.

Ganchev T. 2005. Speaker recognition. [Disertasi]. Patras (GR): Department of Computer and Electrical Engineering, University of Patras.

Li TF, Chang SC. 2003. Speech Recognition of Mandarin Syllables Using both LPCC and MFCC. [Paper]. Institute of Management Ming Dao University, Department of Information Management The Overseas Chinese Institute of Technology.

Nilsson M, Ejnarsson M. 2002. Speech recognition using Hidden Markov Model: performance evaluation in noisy environment. [Tesis]. Blekinge (SE): Blekinge Institute of Technology.

Taufani MF. 2011. Perbandingan Pemodelan Wavelet dan MFCC sebagai Ekstraksi Ciri pada Pengenalan Fonem dengan Teknik Jaringan Syaraf Tiruan sebagai Classifier. [Skripsi]. Bogor (ID): Institut Pertanian Bogor.

Wisnudisastra E, Buono A. 2010. Pengenalan chord pada alat musik gitar menggunakan codeBook dengan teknik ekstraksi ciri MFCC. Jurnal Ilmiah Ilmu Komputer. 14(1):16-21. 